\title{
KEJADIAN ASFIKSIA PADA KETUBAN PECAH DINI DI RUANG NICU RSUD KABUPATEN BULELENG TAHUN 2018
}

\author{
(Asphyxia In Premature Rupture Of Membranes In NICU Room In Public Government \\ Hospital In Buleleng year 2018)
}

\author{
Putu Intan Hartaningrum ${ }^{1}$, Ni Ketut Ayu Wulandari ${ }^{2}$ \\ ${ }^{1}$ Program Studi S1 Kebidanan \\ ${ }^{2}$ Program Studi Profesi Pendidikan Bidan \\ Corespondence author: putuintanhartaningrum@gmail.com \\ Current author: Sekolah Tinggi Ilmu Kesehatan Buleleng
}

\begin{abstract}
ABSTRAK
Pendahuluan: Beberapa faktor telah diteliti sebagai penyebab asfiksia pada bayi baru lahir diantaranya asfiksia yang disebabkan karena ketuban pecah dini. Hal ini tidak terlepas dari pemantauan apgar skor yang dilakukan di ruang NICU RSUD Kabupaten Buleleng. Setiap ibu yang melahirkan yang memiliki riwayat obetetri yang baik dan buruk saat bayinya lahir akan memiliki nilai apgar skor yang berbeda. Adapun tujuan dari penelitian ini adalah untuk mengetahuai kejadian asfiksia pada ketuban pecah dini di ruang NICU RSUD Kabupaten Buleleng. Metode: Jenis penelitian ini retrospektif deskriptif. Hasil: Hasil penelitian menunjukkan bahwa 189 kejadian asfiksia yang disebabkan oleh ketuban pecah dini dengan tingkat asfiksia didapatkan bayi yang mengalami asfiksia ringan sebanyak $43(22,8)$ bayi dan pada asfiksia sedang sebanyak $134(70,9)$ bayi. Dan bayi yang mengalami asfiksia berat sebanyak 12 $(6,3)$ bayi. Kesimpulan dari penelitian yang dilakukan masih banyak kejadian asfiksi yang disebabkan oleh ketuban pecah dini di ruang NICU RSUD Kabupaten Buleleng tahun 2018
\end{abstract}

Kata Kunci : Ketuban Pecah Dini Asfiksia

\begin{abstract}
Introduction: Several factors have is investigated as cause of asphyxia to babies when they are born premature rupture of membranes this case is related to apgar skor result that done in nicu room in public government hospital in buleleng regency. Every mother who hase birth with history of good and bad obetetri when the baby is born will have a different value of Apgar score. The purpose of this study is to know asphyxia in premature rupture of membranes in NICU Room In Public Government Hospital In Buleleng. This research uses descriptive retrospective method in this study the population used are all of asphyxia caused by premature rupture of membranes in NICU Room In Public Government Hospital In Buleleng. Result: The research sample using non probability with total sampling and data collected is through secondary data. Conclusions: The result showed that 189 asphyxia caused by premature rupture of membranes with the level of show thets baby with light asphyxia are 43 (22.8\%) and in moderete asphyxiated are 134 (70.9\%) baby and infants with are $12(6,3 \%)$ infans. conclusion it can be conclude that there are lot of asphyxia caused by premature rupture of membrane in nicu room in public government hospital in buleleng regency year 2018.
\end{abstract}

Keywords: premature Rupture Of Membranes (Asphyxia)

PENDAHULUAN

Angka kematian bayi di dunia masih cukup tinggi. Menurut WHO (2006), angka kematian bayi di dunia mencapai 54 per 1.000 kelahiran hidup dengan pola penyebab 
kematian antara lain infeksi yang meliputi sepsis neonatorum, pneumonia, diare (36\%),

asfiksia neonatorum (23\%), BBLR (27\%), kelainan bawaan (7\%), sebab lain (7\%) (Setya Wandita, 2008). Menurut Survey Demografi Kesehatan Indonesia (SDKI 2003), angka kematian bayi 307 per 100.000 kelahiran hidup (HariSetyobudi, 2008). Angka kematian bayi menurut Mieke (2006) secara keseluruhan di Indonesia mencapai 334 per 100.000 kelahiran hidup dan penyebab kematian terbesar adalah asfiksia neonatorum (Setya Wandita, 2008).

memberikan data yang cepat sehingga pimpinan dapat memberikan respon atau tindakan yang cepat dalam wilayah kerjanya. PWS dimulai dengan program imunisasi yang dalam perjalanannya, berkembang menjadi PWS-PWS lain seperti PWS Kesehatan Ibu dan Anak (PWS KIA) dan PWS Gizi (Depkes, 2010).

Asfiksia adalah kejadian dimana bayi tidak dapat menangis secara spontan dan tratur. Bayi dengan riwayat gawat janin sebelum lahir, umumnya akan mengalami asfiksia pada saat dilahirkan. Masalah ini erat hubungannya dengan gangguan kesehatan ibu hamil, kelainan tali pusat dan kelainan yang mempengaruhi kesejahtraan bayi selama atau sesudah persalinan (asuhan persalinan normal 2007) menurut JMPK-IR (2008). Ketuban pecah dini merupakan salah satu faktor penyebab asfiksia dan infeksi (Midwifery, 2004). Diyatakan bahwa $72 \%$ bayi sepsis berasal dari ibu hamil dengan ketuban pecah dini (Sunarto, 2007).

\section{METODE PENELITIAN}

Jenis penelitian ini retrospektif deskriptif. Variabel penelitian menggunakan satu variabel. Tidak menggunakan populasi, sampel dan teknik sampling. Instrumen pengumpulan data menggunakan dokumen yang diambil dari data sekunder. Analisa data menggunakan grafik bar (colom).

\section{HASIL PENELITIAN}

Tabel 5.1 Distribusi Frekuensi kejadian asfiksia pada ketuban pecah dini berdasarkan umur ibu hamil di Ruang NICU RSUD Kabupaten Buleleng.

\begin{tabular}{ccc}
\hline Umur Ibu & Frekuensi & Presentase \% \\
\hline $15-21$ & 30 & 16 \\
\hline $22-30$ & 79 & 41 \\
\hline $31-45$ & 80 & 43 \\
\hline Total & 189 & 100 \\
\hline
\end{tabular}

berdasarkan dari tabel 5.1 di atas menunjukkan umur ibu yang mengalami Ketuban Pecah Dini hingga menyebabkan bayinya mengalami asfiksia sebagian besar berumur 22-45 tahun.

Tabel 5.2 Distribusi Frekuensi kejadian asfiksia karena ketuban pecah dini berdasarkan tingkat paritas ibu hamil.

$\begin{array}{lll}\begin{array}{l}\text { Tingkat } \\ \text { Paritas }\end{array} & \text { Frekuensi } & \text { Presentase \% }\end{array}$

\begin{tabular}{ccc}
\hline Primigrafida & 81 & 43 \\
\hline Multigrafida & 108 & 57 \\
\hline Total & 189 & 100
\end{tabular}

Dari tabel 5.2 di atas ibu multigrafida lebih banyak yaitu sebanyak 108 orang dan ibu yang primigravida sebanyak 81 orang.

Tabel 5.3 Distribusi frekuensi kejadian asfiksia yang disebabkan karena ketuban pecah dini di ruang nicu RSUD Kabupaten Buleleng dari bulan januari - Desember 2018.

\begin{tabular}{ccc} 
Bulan & $\begin{array}{c}\text { Kejadian } \\
\text { Asfiksia Karena } \\
\text { KPD }\end{array}$ & Presentase \% \\
\hline Januari & 9 & 4 \\
\hline Pebruari & 10 & 5 \\
\hline Maret & 18 & 9 \\
\hline April & 8 & 4 \\
\hline Mei & 10 & 5 \\
\hline Juni & 35 & 18 \\
\hline //ejournal.stikesbuleleng.ac.id/index.php/Midwinerslion $\mid 426$
\end{tabular}




\begin{tabular}{l} 
Juli \\
Agustus \\
\hline September \\
Oktober \\
Novenber \\
Desember \\
Total \\
Berdasarkan tabel 5.3 menunjukkan \\
kejadian bayi asfiksia yang disebabkan oleh \\
KPD sebanyak 189 bayi dari bulan januari \\
sampai desember 2018 . pada bulan januari \\
banyak kejadian asfiksia pada kpd sebanyak 9 \\
bayi, bulan februari sebanyak 10 bayi bulan \\
maret sebanyak 18 bayi pada bulan april \\
sebanyak 8 bayi bulan mei sebanyak 10 bayi \\
bulan juni sebanyak 35 bayi bulan juli \\
sebanyak 24 bayi bulan agustus sebanyak 5 \\
bayi September 15 bayi oktober 25 bayi \\
November 20 bayi dan pada bulan desember \\
sebanyak 12 bayi.
\end{tabular}

Tabel 5.4 Distribusi frekuensi kejadian asfiksia pada Ketuban Pecah Dini berdasarkan tingkat asfiksiadi Ruang Nicu RSUD Buleleng tahun 2018

\begin{tabular}{lll}
\hline Kategori & Frakuensi & Presentase \% \\
\hline $\begin{array}{l}\text { Asfiksia } \\
\text { Ringan }\end{array}$ & 43 & 22,8 \\
\hline $\begin{array}{l}\text { Asfiksia } \\
\text { Sedang }\end{array}$ & 134 & 70,9 \\
\hline $\begin{array}{l}\text { Asfiksia } \\
\text { Berat }\end{array}$ & 12 & 6,3 \\
\hline Total & 189 & 100 \\
\hline
\end{tabular}

Berdasarkan $\quad$ Tabel 5.4 diatas menunjukkan dari 189 kejadian asfiksia yang disebabkan oleh kpd dengan tingkat asfiksia didapatkan bayi yang mengalami asfiksia ringan sebanyak 43 bayi dan pada asfiksia sedang sebanyak 134 orang. Dan bayi yang mengalami asfiksia berat sebanyak 12 bayi.
Tabel 5.5 Frekuensi Umur Kehamilan Ibu Yang Mengalami Ketuban Pecah Dini Dengan Tingkat Asfiksia.

\begin{tabular}{|c|c|c|c|}
\hline \multirow[t]{2}{*}{$\begin{array}{c}\text { Kategori } \\
\text { umur } \\
\text { kehamilan }\end{array}$} & $\begin{array}{c}\text { Asfiksia } \\
\text { ringan }\end{array}$ & $\begin{array}{c}\text { Asfiksia } \\
\text { sedang } \\
4-6)\end{array}$ & $\begin{array}{c}\text { Asfiksia } \\
\text { berat } \\
(0-3)\end{array}$ \\
\hline & $\begin{array}{l}\text { (f) } \\
(\%)\end{array}$ & $\begin{array}{l}\text { (f) } \\
(\%)\end{array}$ & $\begin{array}{l}\text { (f) } \\
(\%)\end{array}$ \\
\hline Preterm & $\begin{array}{l}9 \\
19\end{array}$ & $\begin{array}{l}8 \\
6\end{array}$ & \\
\hline Aterm & $\begin{array}{l}37 \\
80\end{array}$ & $\begin{array}{l}118 \\
88\end{array}$ & 12 \\
\hline Postterm & & $\begin{array}{l}7 \\
5\end{array}$ & I \\
\hline Total & 46 & 133 & 13 \\
\hline
\end{tabular}

Berdasarkan table 5.5 diatas menunjukkan dari 189 kejadian asfiksia yang disebabkan oleh kpd berdasarkan dari umur kehamilan dan tingkat asfiksia dimana ibu yang kehamilannya kurang buulan atau preterem mengalami asfiksia ringan sebanyak 9 bayi dan pada asfiksia sedang sebanyak 8 orang. Dan ibu yang melahirka cukup bulan atau aterm yang mengalami asfiksia ringan sebanyak 37 bayi dan yang mengalami asfiksia sedang sebanyak 118 bayi dan yang mengalai asfiksia berat sebanyak 12 orang. Sedangkan ibu yang mengalami kehamilan lewat bulan atau postterm hanya 7 banyi yang mengalami asfiksia sedang sedangkan yang menagalanmi asfiksia berat sebanyak 1 orang

\section{PEMBAHASAN}

Berdasarkan analisis data banyi yang mengalami asfiksia karena kpd kebnanyakan mengalami asfiksia sedang yaitu berjumlah 134 bayi dan yang mengalami asfiksia ringan sebanyak 43 bayi dan 12 bayi mengalami asfiksia berat. Asfiksia adalah kejadian dimana bayi tidak dapt menangis secara spontan dan tratur. Bayi dengan riwayat gawat janin sebelum lahir, umumnya akan mengalami asfiksia pada saat dilahirkan. Masalah ini erat hubungannya dengan gangguan kesehatan ibu hamil, kelainan http://ejournal.stikesbuleleng.ac.id/index.php/Midwinerslion | 427 
talipusat dan kelainan yang mempengaruhi kesejahtraan bayi selama atau sesudah persalinan (Asuhan Persalinan Normal, 2007) menurut JMPK-IR (2008).

Asfiksia pada bayi baru lahir adalah suatu keadaan dimana bayi tidak dapat bernafas cecara spontan dan teratur segera setelah lahir. Hal ini disebabakan oleh karena hipoksia ( kekurangan oksigen) janin dalam kandungan yang terjadi saat kehamilan, persalinan atau segera setelah bayi lahir. Hipoksia dapat menghambat adaptasi bayti baru lahir terhadap kehidupan diluar rahim ibu. Sekitar 9,8\% dari seluruh kematian bayi baru lahir disebabkan oleh asfiksia yang terjadi waktu lahir ( anik dan Nurhayati, 2008 hal 154). Beberapa faktor tertentu dapat menjadi asfiksia pada bayi baru lahir, diantaranya adalah factor ibu seperti preeklamsi dan eklamsia perdarahan abnormal, plasenta previa atau solusi plasenta. Partus lama atau partus macet, demam selama persalinan ketuban pecah dini dan infeksi berat., factor tali pusat seperti lilitan tali pusat, tali pusat pendek, simpul tali pusat. faktor bayi seperti bayi premature, persalinan dengan tindakan ( sunsang, bayi kembar, distosia bahu, ekstraksi bahu, ekstraksi vakum, ekstraksi forsep, seksio caesaria), kelainan bawaan, air ketuban bercampur mekonium.

Kejadian asfiksia selama satahun sebanyak 189 bayi, dan berdasarkan dari umur kehamilan dan tingkat asfiksia dimana ibu yang kehamilannya kurang buulan atau preterem mengalami asfiksia ringan sebanyak 9 bayi dan pada asfiksia sedang sebanyak 8 orang. Dan ibu yang melahirka cukup bulan atau aterm yang mengalami asfiksia ringan sebanyak 37 bayi dan yang mengalami asfiksia sedang sebanyak 118 bayi dan yang mengalai asfiksia berat sebanyak 12 orang. Sedangkan ibu yang mengalami kehamilan lewat bulan atau postterm hanya 7 banyi yang mengalami asfiksia sedang sedangkan yang menagalanmi asfiksia berat sebasnyakl 1 orang.

Menurut JNPK-KR (2008), ketuban pecah dini merupakan salah satu penyebab asfiksia, ketuban pecah dini ini meningkatkan resiko terjadinya infeksi sehingga menyebabkan hipoksia pada bayi. Hipoksia pada bayi dapat menimbulkan reflek respirasi bayi dalam rahim sehingga mekonium dapat juga masuk kedalam paru bayi jika tersendak saat lahir. Masuknya mekonium ke jaringan paru bayi dapat menyebabkan peneumonia dalam air ketuban pada presentasi kepala menunjukkan adanya gangguan oksigen. Selama di dalam uterus bayi meminum air ketuban, jadi jika air ketuban berwarna keruh mengakibatkan terjadinya oksigen sehingga bayi sulit untuk bernafas secara baik yang pada akhirnya akan menimbulkan asfiksia pada bayi baru lahir.

Berdasarkan umur kehamilan dari 189 bayi sebagian besar bayi lahir pada umur kehamilan aterm yaitu sebnayak 168 orang dan umur kehamilan preterm sebanyak 14 dan pada hehamilan postterm sebanyak 7 orang. Persasalinan dianggap normal bila prosesnya terjadi pada usia kehamilan 37-40 minggu atau aterm tampa disertai penyulit. Walaupun persalinan berlangsung secara normal atau spontan tidak menutup kemungkinan terjadinya sfiksia pada bayi tersebut. Postterem adalah kehamilan yang berlangsung lebi dari perkiraan hari tafsiran hari tafsiran persalinan yang dihitung dari hari pertama haid teraksir (HPHT) dimana umur kehamilannya melebihi 42 minggu (frindster, 2008).

Resiko terhadap janin disebabkan oleh karena proses penuaan plasenta sehingga terjadi gangguan fungsi plasenta (insufisiensi) kehamilan lewat waktu tidak mapu memberikan nutrisi atau pertukaran $o^{2}$ sehingga janin mempunyai resiko asfiksia sampai kematian dalam rahim. Kehamilan kurang bulan atau preterm yaitu kehamilan krang dari 30 minggu antara 20-37 minggu, dampak pada kelahiran premature salah satunya adalah pembentuk organ yang belum sempurna setelah bayi dilahirkan. Seperti paru-paru dan saluran cerna yang belum matang. Bayi akan mudah mengalami hipotermi (kedinginan) mudah mengalami 
infeksi dan hipoglikemi ( gula darah yang rendah) pada bayi yang mengalami kurang bulan biasanya akan mengalami kekurang oksigen sehingga akan mengalami pernafasan yang cepat daalm periode yang singkat. Apabila berlanjut gerakan bernafas akan berhenti (Alvavotage).

\section{SIMPULAN DAN SARAN Simpulan}

Kejadian bayi asfiksia yang disebabkan oleh KPD sebanyak 189 bayi dari bulan januari sampai desember 2018. Dari 189 bayi yang mengalami asfiksia karna KPD di ruang NICU RSUD Kabupoaten Buleleng, 143 bayi mengalami asfiksia sedang $(22,8 \%)$, $43(70,9)$ bayi mengalami asfiksia ringan dan 12 ( 6,3$)$ bayi yang mengalami asfiksia berat. kejadian asfiksia yang disebabkan oleh kpd berdasarkan dari umur kehamilan dan tingkat asfiksia dimana ibu yang kehamilannya kurang buulan atau preterem mengalami asfiksia ringan sebanyak 9 bayi dan pada asfiksia sedang sebanyak 8 orang. Dan ibu yang melahirka cukup bulan atau aterm yang mengalami asfiksia ringan sebanyak 37 bayi dan yang mengalami asfiksia sedang sebanyak 118 bayi dan yang mengalai asfiksia berat sebanyak 12 orang. Sedangkan ibu yang mengalami kehamilan lewat bulan atau postterm hanya 7 banyi yang mengalami asfiksia sedang sedangkan yang menagalanmi asfiksia berat sebasnyakl 1 orang.

\section{Saran}

Hasil penelitian ini diharapkan dapat dikembangkan bagi institusi kebidanan, institusi tempat penelitian dan peneliti selanjutnya, diharapkan hasil penelitian ini dapat dijadikan sebagai acuan atau bahan masukan dan sumber informasi dalam melakukan penelitian selanjutnya dan mampu mendalami teori yang ada untuk memberikan pengetahuan yang berkaitan dengan kejadian adfiksia karena Ketuban Pecah Dini dan diharapkan peneliti selanjutnya mampu membuat penelitian tentang cara menekan peningkatan asfiksia pada bayi baru lahir.
Manuaba,ida Bagus Gede 2008. Ilmu kebidanan, penyakit kandungan dan keluarga berencana untuk pendidikan bidan.jakarta: ECG

Prawirohardjo, Sarwono. 2009. Pelayanan Kesehatan Maternal dan Neonatal. Jakarta: PT Bina Pustaka Sarwono Prawirohardjo.

Prawirohardjo, Sarwono. 2009. Ilmu Kebidanan.Jakarta: PT Bina Pustaka Sarwono Prawirohardjo.

\section{DAFTAR PUSTAKA}

